Relations industrielles

Industrial Relations

\title{
The Europeanisation of Social Protection, Edited by Jon Kvist and Juho Saari, Bristol: Policy Press, 2007, 308 pp., ISBN 978-1-84742-019-0 (paperback) and ISBN 978-1-84742-020-6 (hardcover).
}

\section{Hedva Sarfati}

Volume 64, numéro 3, été 2009

URI : https://id.erudit.org/iderudit/038560ar

DOI : https://doi.org/10.7202/038560ar

Aller au sommaire du numéro

Éditeur(s)

Département des relations industrielles de l'Université Laval

ISSN

0034-379X (imprimé)

1703-8138 (numérique)

Découvrir la revue

Citer ce compte rendu

Sarfati, H. (2009). Compte rendu de [The Europeanisation of Social Protection, Edited by Jon Kvist and Juho Saari, Bristol: Policy Press, 2007, 308 pp., ISBN 978-1-84742-019-0 (paperback) and ISBN 978-1-84742-020-6 (hardcover).] Relations industrielles / Industrial Relations, 64(3), 539-541.

https://doi.org/10.7202/038560ar

Tous droits réservés (C Département des relations industrielles de l'Université Laval, 2009
Ce document est protégé par la loi sur le droit d'auteur. L'utilisation des services d'Érudit (y compris la reproduction) est assujettie à sa politique d'utilisation que vous pouvez consulter en ligne.

https://apropos.erudit.org/fr/usagers/politique-dutilisation/ 
équitable de la banane dans les Caraïbes. Au nord, il s'agit des dockers européens en lutte contre les directives de la Commission Européenne, des efforts de coordination des métallos européens puis des alliances transatlantiques du SEIU. Ces cas de campagnes transfrontalières sont suivis de deux chapitres qui s'intéressent aux conditions contrastées de l'action syndicale à l'international, du potentiel des nouveaux espaces de régulation (les accords-cadres internationaux) à la permanence de formes violentes de répression syndicale.

Il s'agit d'une collection éclectique de contributions, ce qui est normal pour un ouvrage issu d'une conférence et compte tenu de la problématique à l'examen. Ces contributions sont toutes individuellement de très bon calibre, pour le lecteur intéressé. Ensemble elles illustrent bien le contexte adverse et le caractère complexe de l'internationalisme syndical, mais elles illustrent aussi que la formation de solidarités élargies n'est pas non plus chose insurmontable, ce qui va dans le sens de la ligne d'édition de l'ouvrage.

Pour le lecteur hâtif qui veut faire l'économie des chapitres empiriques, Kate Bronfenbrenner produit un excellent travail de synthèse dans le chapitre de conclusion. Elle y discute l'importance de la régulation étatique et de ses manques, parfois complices, en ce qui a trait au respect des droits des travailleurs. Elle y souligne l'importance de l'éducation syndicale et de son rôle dans l'activation de réseaux de solidarité. Elle y réitère finalement l'importance de la recherche au service de campagnes syndicales ainsi informées des points de vulnérabilité du capital international, et la nécessité d'un syndicalisme global faisant front commun au nom de la justice sociale, seul moyen, selon l'auteure, pour que les solidarités parviennent à prendre le dessus.

En somme, il s'agit d'un ouvrage qui se veut constructif, et il y parvient - le site internet de la conférence indiqué dans le premier chapitre peut d'ailleurs s'avérer très utile pour l'enseignement ou pour l'éducation syndicale. II s'agit aussi d'un ouvrage qui conjugue efficacement réalisme et idéalisme. Bien sûr, si I'on s'y attache, on pourra trouver des contre- exemples. On pourrait également questionner dans quelle mesure la crise qui vient de frapper l'économie mondiale va mettre les solidarités à l'épreuve, pour le meilleur ou pour le pire? Mais que l'on partage ou non l'optimisme de l'éditrice, cet idéalisme, cette volonté d'optimisme reflète bien le changement de ton qui est dans l'air du temps.

\section{Stéphane Le Queux}

Griffith University

\section{The Europeanisation of Social Protection}

Edited by Jon Kvist and Juho Saari, Bristol: Policy Press, 2007, 308 pp., ISBN 978-1-84742019-0 (paperback) and ISBN 978-1-84742-020-6 (hardcover).

This book looks at the broad policy areas encompassed by social protection and covers many more 11 EU member States, selected for their institutional, cultural and political differences. The analysis and reflections are most timely in the current context of EU at the cross-roads, with the outcome of the Lisbon Treaty ratification unknown, the heavy social toll of the recession in the wake of the financial crisis hitting all member States, and the growing public deficits limiting further Governments' capacity to address it.

The book starts with a statement that "EU member States remain largely responsible for social policy and EU competence is limited by the principles of subsidiarity and proportionality. However, social policy at national level is increasingly influenced by the European Union, in fact, even more so than was anticipated 10 years ago." (p. vi). And it is the description of how this influence evolved and can evolve, as a result of growing shared concerns and challenges among member States, that I found the book most interesting and stimulating.

Indeed it seems generally taken for granted that if there should be any influence - it is through EU Commission increasingly encroaching on national sovereignty - a trend that is strongly opposed by member States, particularly in the broad area of social policy. The authors however show how impetus can be given by the EU to improve national policy-making and by increasing cooperation among member States by emulating success- 
ful policies and practices and cooperation with the EU Commission to strengthen the EU social dimension and its visibility, including the much debated Open Method of Coordination (OMC). The EU has in fact created a new environment for member States' social protection systems. The EU competition, single market and economic policies, the basic four freedoms of movement (labour, capital, goods and services), the European Monetary Union (EMU) and EU enlargement exert an impact on social protection systems. To turn this new environment into a positive opportunity requires a greater emphasis on shared social values, which the book illustrates.

The book analyses how member States react and respond to these EU developments, assessing the impact of recent EU developments on national social protection systems, and how governments' responses to different EU Commission proposals, recommendations and policies reflect their institutional structures and social protection reforms, and their perception and vision of the future of the European social model (ESM). The analysis of national basic attitudes and responses (support, resistance or indifference) relates to four areas relevant to social protection in which Government responses and EU policies can be considered as mutually reinforcing, namely: policy processes (Lisbon Strategy, Social Policy Agenda, OMC and demographic change); the interplay between internal markets and social policy (the Services Directive and Services of general interest), and the socio-political implications of the EMU and of EU enlargement in 2004 and 2007. The analysis improves the understanding of the processes of Europeanization and, the authors argue, could make it possible to formulate a stronger platform for future debate on European social protection policies.

The bulk of the book is devoted to country studies that reflect the diversity of membership, to which 11 of the 14 chapters are devoted, namely the Czech Republic, Denmark, Finland, France, Germany, Greece, Italy, the Netherlands, Poland, Spain and the UK. The first chapter offers a synthesis of the evolving perspectives of EU policies in social protection in the four areas, noting that there is already strong evidence at EU level of Europeaniza- tion of social protection - with the Council of ministers and the Commission being increasingly active in this area, sharing information, proposing guidelines and sometimes using OMC. The impact of the European Court of Justice (ECJ) rulings is also mentioned. There is a dense web of communications on a growing number of issues related to social protection, that enable governments to develop and formulate more substantiated policy positions in response to the new relationship between the EU-level institutions and social protection. Arguably not all member States are equally prepared for such process, but as European integration proceeds political pressure and the need for such activity will increase.

Chapter 13 synthesizes the findings of the national case studies, concluding that the most striking feature of the process is that "EU-level developments increasingly interact with social protection in all countries" (p.248).

Chapter 14 traces the quest for a new balance between social and economic concerns in the $\mathrm{EU}$, noting that after the introduction of the Lisbon Strategy and the OMC, systematic attention has been focused on the social dimension of European integration at the EU level, as evidenced by the high level meetings of social Europe convened by all recent EU presidencies, the regular reference to the concept of the European social model which appears to unite the different welfare regimes. The EU Social Protection Committee (SPC) has been established under the Nice Treaty to share information among member States and define strategic objectives - clearly an area for cooperation with the Commission. Moreover, the role of the European Parliament is becoming more significant with the extension of co-decision making. For the authors this means that the social dimension of the EU can no longer be ignored.

To help clarify the substance of this dimension the authors provide a useful reminder of the history of the EMS, which arguably means widely differing concepts to different countries. It is therefore particularly useful that they highlight 10 common features of this multidimensional concept which are shared by all or most EU member States and they are essential for comprehensive policy making. These in- 
clude, shared values (social market economy, solidarity, social cohesion, equal opportunities, universal access to health care and education and the recognized role for social partners and civil society); common challenges (globalization, new global power structures, economic restructuring and post-industrialism, aging, new family structures, unemployment and atypical employment, lack of social cohesion and inclusion, long-term instability and public deficits, and... the potential for both positive and negative outcomes of EU integration which has a potentially major impact on the socio-economic dynamics of the EU); common policy responses (when adjusting their social protection systems, member States respond in roughly similar ways by paying systematic attention to: poverty among vulnerable groups, reconciliation of work and family, better health, activation and longer working lives, incentive structures and sustainable health care, investing much in policy coordination between labour and social policies, though to a lesser extent between these policies and health policies); common institutional environment (EU membership, EU law (directives, ECJ rulings), EMU, ECB); common policy processes (European Employment Strategy, Broad Economic Policy Guidelines etc.); commitment to the welfare state/society (the important role of public sector and welfare state in allocating resources via redistributive mechanisms, the role of services of general interest, and legislation which promotes the well-being of citizens).

The authors argue that the European welfare states have been transformed into semisovereign welfare states, as the institutional structure of the internal market rapidly evolves to cover fields directly related to social and health policies. The Treaties of Maastricht, Amsterdam and Nice established and extended the idea of a European citizenship. For example, the EU regulation on social security coordination (1408/71) covers both third-country nationals and the non active population. ECJ rulings increasingly link entitlement to transfers and services to the free movement of all, not to specific nationals. Thus, the rights related to the four freedoms may result in some economic and political pressures on national social protection systems for financing. The common challenges of demographic ageing may make recommendations from EU bodies more palatable to national policy-makers. The joint commitment to the Stability and Growth Pact may pressure member States to consider EU views on their reform policies. As the economic sustainability and stability of member States increasingly depend on rising pension and health care expenditure, there will be stronger EU economic pressures on national social policy planning, though at present different EU bodies deal separately with the economic and social fields.

The main conclusion of the book is that there is need to accept the existence of very common social policy interests at the EU level, that extensive cooperation on social policy is needed instead of confrontation, and that social cohesion, economic growth and high employment are mutually reinforcing, as shown in the excellent growth record of countries that have invested in social protection and social cohesion.

In sum, this is a highly timely and useful book for decision makers, social actors and academics concerned by the current economic and social challenges facing Europe.

\section{Hedva Sarfati \\ ISSA Consultant on Labour Market and \\ Welfare reforms}

\section{L'approche systémique de la gestion des ressources humaines: le contrat psychologique des relations d'emploi dans les administrations publiques du $\mathrm{xxI}^{\mathrm{e}}$ siècle}

Par Louise Lemire et Gaétan Martel, Québec : Presses de I'Université du Québec, 2007, 412 p., ISBN 978-2-7605-1494-2.

Dans un contexte socio-économique en pleine évolution, plusieurs auteurs s'intéressent au concept de contrat psychologique qui permet d'appréhender les relations d'emploi et de rendre compte de la dynamique au sein de celles-ci. C'est d'ailleurs l'objet du présent ouvrage qui s'intéresse aux relations d'emploi et, plus particulièrement, à l'évolution du contrat psychologique qui lie les employés à leur organisation, dans le cadre particulier des administrations publiques. En effet, le processus de modernisation et de renouvellement 